\title{
"Digital transformation leads to new jobs creation with higher wages." Interview with Boris Vujčić, Governor, Croatian National Bank
}

This year the Lamfalussy Award was received by Boris Vujčić, Governor of the Croatian National Bank. The Lamfalussy Award, established by the National Bank of Hungary is dedicated to recognise exceptional international achievements influencing international monetary policy. We are honored to be able to conduct the following interview with Governor Vujčić, that can help us to better understand the economic policy and thinking in our region, in Central and Eastern Europe.

Tamás Pesuth: What are the strategic challenges for the central banks worldwide with regards to restarting the economies after COVID-19? What is the potential danger of the increased debts of the governments and what kind of strategic coordination is necessary with fiscal policy to manage the debts?

Boris Vujčić: Main challenge for the central banks from emerging markets during the onset of the crises was to stabilize financial markets, in particular the exchange rate market and the bond market, while maintaining favorable financing conditions and supporting access to liquidity for the non-financial sector. A year on, the challenge shifts towards other economic policies that have somewhat longer perspective. As recovery is advancing and economic activity gradually normalizes, the main challenge for central banks will be to keep risks for financial stability at check. Accommodative monetary policy in part operates by encouraging financial system to take more risk. But, as we expect the loan quality to worsen and prolonged period of low interest rates to squeeze the lending margins further, central banks will need to stay vigilant for signs of exuberance in the financial cycle. Fiscal policy is part of this story. The debt considerations have been significantly relaxed during the pandemic. However, we have seen over and over again how destructive the bank-sovereign nexus can become when we get on the wrong side of public debt sustainability metrics. Borrowing in dollars or other hard currencies, which is important for many emerging markets, adds another layer of risks. The most important preconditions for central banks to successfully navigate troubled waters ahead is to maintain independence and their ability to counter any type of external pressures, transparently elaborating to the public their deliberations.

T. P.: How can the European Union contribute to the stabilisation and growth of its own economy and the world economy? What kind of renewal is it necessary in the economic thinking and in the monetary and fiscal policy in practice?

B. V.: Economic activity is expected to rebound sharply in 2021 , yet it will take some time to return to the pre-crises level. Service sectors with close contact, such as tourism or creative industries and those that closed during lockdowns, will suffer the most in the near term. But it is also an opportunity for Europe to re-start and re-invent itself.

Already prior to the pandemic the fiscal policy and monetary policy nexus has changed. It is due to diverse structural factors such as lower productivity growth, ageing society and global savings glut that real interest rate has fallen and is expected to remain "lower for longer". As a result, conventional monetary policy tools are less likely to be able to stabilize the economy leading to ample use of unconventional monetary measures.

Now, well into second year of pandemic, low interest rate environment is sustaining demand and employment to help businesses stay afloat. Also, fiscal spending seems to be more effective close to the 
effective lower bound as investors do not anticipate a tightening of monetary policy following a fiscal expansion, as they would in a normal setting. Debt servicing costs have fallen, so as long as interest rates are lower than nominal growth rates there is no need to run primary budget surpluses to stabilize their debt ratios. However, once the recovery is well on its way, fiscal consolidation should take place and unconventional monetary policy support should be gradually rolled back. Otherwise, the prolonged monetary stimulus could lead to adverse effects including keeping alive the "zombie" firms and to other effects that are harmful to long term recovery. Exactly for that reason we should not lose sight of structural reforms and other policies needed for raising the long-term growth potential.

\section{T. P.: How can the European Union integrate itself to the post-COVID-19 economic environment? How can central banks help the strengthening of the knowledge based economies and the inevitable technological renewal that is taking place in our societies?}

B. V.: Central banks, in fulfilling their mandate, cannot pick winners in the area of technological progress. Mandate in price stability and other tasks should be carried out respecting "market neutrality" principle supporting carbon light and knowledge heavy industries, without introducing market distortions. This is precisely the point I raised before, where policies beyond fiscal and monetary are needed. Traditional macroeconomic policies can alleviate short-term damage from financial and even health crises, but they alone are far from enough to facilitate technological renewal and raise the long-term growth potential. There are no simple recipes on how to achieve that, we need many structural reforms, more business-friendly regulations, education systems better suited to the needs of 21 st century, smart public investments and a host of other reforms.

If we are lucky and manage to get at least some those policies right, it could boost productivity growth that has been stagnant for some time, especially in Europe. Digital transformation leads to new jobs creation with higher wages. Moreover, knowledge based economy could lead to a less resource-intensive economy, that is less reliant on carbon emissions and that can be decoupled from economic growth more quickly. Still, we need to think of those left behind as technological progress shifts economic activity to innovative industries, leaving regional and sectoral "pockets" of unemployment in previously successful industries and areas.

T. P.: What are the new perspectives our countries in the CEE region? Does the extension - and later the completion - of the eurozone require a new thinking in the European finances?

B. V.: The pandemic disrupted the normal functioning of the economy, but it paved the way to new perspectives. In the EU, the Next Generation package can increase the structural resilience and growth potential of the EU. It has inbuilt goals for green transition and digital transformation objectives. On the financial side, it will lead to the creation of a safe asset, which will help the implementation of monetary policy within the euro-area. The successful use of EU funds, disbursed through multiannual financial framework, should have a significant impact on the strength of recovery of the regional economy and should reinforce the sustainability of external positions. Further integration steps in the form of the Banking Union and the Capital Markets Union will provide additional stimulus to growth. Once the recovery is on its way, fiscal consolidation should be gradual and growth friendly measures should be adopted.

Against this backdrop, the CEE region faces additional challenges. Unconventional monetary policy measures, like large scale-asset purchases and liquidity injections, were developed and used by major central banks during the Great financial crisis, while the COVID-19 pandemic triggered smaller central banks to start using similar measures. Hence, in terms of available policy options, central banks in CEE 
region have a wider range of instruments. Main concern today is mostly fiscal, namely how to withdraw all available funds, especially grants, and more importantly how to spend them most effectively towards project contributing towards long term growth and sustainable recovery.

\section{T. P.: Will the management of the technological changes and the climate change have a significant effect on monetary policy? What roles do central banks play in these issues?}

B. V.: The tasks and duties of central banks have not changed in the last decade, but the world has. We see an influx of non-financial players providing banking and other financial services in the areas traditionally reserved for banks. These players rely heavily on technology and promise to democratize finance by reaching all those previously financially underserved. To fulfil the promise, they move fast and break things. So the traditional approach to the conduct of monetary policy could also become challenged in a world of new financial intermediaries or in a world of solely technology-based intermediaries. We need to constantly ask ourselves how would monetary policy transmission be carried out with diminishing importance of banks and how would the financial system look like with significantly reduced demand for central bank balances. Who will be held responsible if some of these technological innovations, such as virtual currencies, lose public support and what can we do in order to preserve financial stability.

To prevent undesirable events, central banks must follow a balanced but firm approach and remain technology neutral at the same time. While working actively on understanding and mitigating risks, central banks must not supress market developments by limiting the use of technology. Accommodative monetary policy in combination with the low interest rate environment is conducive to financial innovations and it is important to find the way how to incentivize the economy without accumulating systemic imbalances. In the same way that the technology enabled an unprecedented number of individuals to be involved in finance, central bankers need to develop their own technological solutions and strengthen international coordination in monetary and financial supervisory policies.

Just as the world is changing thanks to the technological progress, it is as also changing due to the longterm impact of harmful human activities on our climate and environment. The magnitude and speed of climate change as well as of the ensuing global warming and incidence of extreme weather events, imply pronounced financial risks. Central banks should be aware of those risks and make sure that the financial institutions they supervise also properly understand, assess and manage those risks so as to prevent their potential losses.

Climate change and the transition to climate-friendly economy have the effect on short and long-term economic development through different transmission channels. Therefore, understanding of those mechanisms is important for the successful achievement of standard central banks' goals - maintaining price stability and contributing to financial stability. In my opinion, it is important for the central banks to strengthen the capacities of their research and analytical departments to identify climate-related shocks that might have impact on their inflation outlook, and that might as well jeopardize the financial stability. Obviously, due to the complexity of the to-day's world, it has become rather challenging to be a central banker.

Tamás Pesuth ${ }^{1}$

${ }^{1}$ associate professor, CUB

DOI: 10.14267/RETP2021.01.01 